\title{
GEOTECTONIC REGIME OF FORMATION OF THE COAL-BEARING DEPOSITS IN THE WESTERN DONETS BASIN (UKRAINE)
}

\author{
A.V. Ivanova1, L.B. Zaitseva², O.I. Spirina ${ }^{3}$ \\ (Recommended by doctor of geological sciences M.I. Yevdoshchuk)
}

${ }^{1}$ Institute of Geological Sciences of NAS of Ukraine, Kyiv, Ukraine, E-mail: ariadna.v.ivanova@gmail.com. Doctor of geological sciences.

${ }^{2}$ Institute of Geological Sciences of NAS of Ukraine, Kyiv, Ukraine, E-mail: ariadna.v.ivanova@gmail.com. Senior scientific worker.

${ }^{3}$ AUPO (All-Ukrainian Public Organization) "Ukrainian Association of geologists", Kyiv, Ukraine,

E-mail: spirolesya@ukr.net

Independent expert, geologist-scientist.

The geotectonic regime of the Western Donbass determined the conditions for peat accumulation, changes in phytocoenoses, formation of petrographic composition, and the nature of the transformation of organic matter, which affected the quality of coal. Hercynian tectogenesis determined the geothermal conditions of the region and the degree of coalification of organic matter, and activation of the hydrogeological regime as an additional factor of desalting of coals. In the Early Carboniferous on the swampy lagoon coast of the shallow sea, grassy vegetation was formed, which was the initial material for coals with a low and medium content of vitrinite. In the Middle Carboniferous, the treelike vegetation grew on the coastal-marine lowland, from which coals with a high and moderately high content of vitrinite were formed. The thickness of coal-bearing strata and the degree of coalification (metamorphism) increases in the eastern direction. A characteristic feature of coal is salinity as a result of the influence of sea water on the organic matter during peat formation. Salinity of coals decreases with increasing degree of coalification. Hercynian tectogenesis led to the erosion of Upper Paleozoic deposits with a thickness of about $3 \mathrm{~km}$.

Key words: Western Donbas; geotectonics; coal-bearing capacity; coal petrography; geothermics; coal metamorphism; sodium; chlorine.

\section{ГЕОТЕКТОНІЧНИЙ РЕЖИМ ФОРМУВАННЯ ВУГАЕНОСНИХ ВІАКАААІВ ЗАХІАНОГО АОНБАСУ (УКРAÏHA)}

\author{
А.В. Іванова1, Л.Б. Зайцева², О.І. Спіріна³ \\ (Рекомендовано д-ром геол. наук М.I. Свдощуком)
}

${ }^{1}$ Iнститут геологічних наук НАН Украӥни, Київ, Украӥна, E-mail: ariadna.v.ivanova@gmail.com Доктор геологічних наук, провідний науковий співробітник.

${ }^{2}$ Інститут геологічних наук НАН Украӥни, Київ, Україна, E-mail: ariadna.v.ivanova@gmail.com Стариий науковий співробітник.

${ }^{3}$ ВГО «Спілка геологів України», Київ, Україна, E-mail: spirolesya@ukr.net

Незалежний експерт, геолог-науковець.

Геотектонічний режим Західного Донбасу визначив умови торфонакопичення, зміни фітоценозів, характер перетворення органічної речовини, формування петрографічного складу та якості вугілля. Герцинський тектогенез визначив геотермальні умови регіону і ступінь вуглефікації органічної речовини, активізацію гідрогеологічного режиму як додаткового фактора знесолення вугілля. В ранньому карбоні на заболочених лагунах мілкого морського узбережжя формувалася трав'яниста рослинність, що слугувала похідним матеріалом для вугілля з низьким і середнім вмістом вітриніту. В середньому карбоні на прибережно-морській низовині була поширена деревовидна рослинність, $з$ якої формувалося вугілля з високим і помірно високим вмістом вітриніту. Показники якості вугілля як нижнього, так і середнього карбону залежать від ступеня вуглефікації (метаморфізму), який росте у східному напрямку. Характерною особливістю вугілля є засолення в результаті

(c) A.V. Ivanova, L.B. Zaitseva, O.I. Spirina, 2018 
впливу морських вод на органічну речовину під час торфоутворення. Солоність вугілля зменшується із зростанням вуглефікації. Герцинський тектогенез сприяв розмиву верхньокарбонових-нижньопермських відкладів потужністю приблизно 3 км.

Ключові слова: Західний Донбас; геотектоніка; вугленосність; вітриніт; ліптиніт; інертиніт; геотермія; метаморфізм; якість вугілля; відновленість вугілля; солоне вугілля.

\title{
ГЕОТЕКТОНИЧЕСКИЙ РЕЖИМ ФОРМИРОВАНИЯ УГАЕНОСНЫХ ОТАОЖЕНИЙ ЗАПААНОГО АОНБАССА (УКРАИНА)
}

\section{А.В. Иванова1, Л.Б. Зайцева2, О.И. Спирина}

(Рекомендовано д-ром геол. наук Н.И. Евдощуком)

\begin{abstract}
${ }^{1}$ Институт геологических наук НАН Украины, Киев, Украина, E-mail: ariadna.v.ivanova@gmail.com Доктор геологических наук, ведущчий научный сотрудник.

${ }^{2}$ Институт геологических наук НАН Украины, Киев, Украина, E-mail: ariadna.v.ivanova@gmail.com Стариий научный сотрудник.
\end{abstract}

${ }^{3}$ ВОО «Союз геологов Украинь»», Киев, Украина, E-mail: spirolesya@ukr.net

Независимый эксперт, геолог-ученый.

Геотектонический режим Западного Донбасса определил условия торфонакопления, изменения фитоценозов, характер преобразования органического вещества, формирования петрографического состава и качества углей. Герцинский тектогенез определил геотермальные условия региона и степень углефикации органического вещества, активизацию гидрогеологического режима как дополнительного фактора обессоливания углей. В раннем карбоне на заболоченном лагунном побережье мелкого моря формировалась травянистая растительность, которая была исходным материалом для углей с низким и средним содержанием витринита. В среднем карбоне на прибрежно-морской низменности произрастала древовидная растительность, из которой формировались угли с высоким и умеренно высоким содержанием витринита. Показатели качества углей как нижнего, так и среднего карбона зависят от степени углефикации (метаморфизма), которая возрастает в восточном направлении. Характерной особенностью углей является засоление в результате влияния морских вод на органическое вещество во время торфообразования. Соленость углей уменьшается с ростом степени углефикации. Герцинский тектогенез привел к размыву верхнепалеозойских отложений мощностью около 3 км.

Ключевые слова: Западный Донбасс; геотектоника; угленосность; витринит; липтинит; инертинит; геотермия; метаморфизм; качество углей; восстановленность углей; соленые угли.

\section{Introduction}

The Western Donbass is located in the Dnipropetrovsk region in the Samara river basin and borders with the South-Western Donbas of the Donetsk region. The influence of geotectonics on peat accumulation conditions and formation of the matter petrographic composition of the Lower and Middle Carboniferous coals was studied in the Petrykivsky, Novomoskovsky and Pavlogradsko-Petropavlivsky coal industrial areas in 80 s years of the XX centure. The studies were carried out on the cores of the wells and the samples of operating mines. The results of these investigations they were lighted up in the published papers [Иванова, 1985; Иванова, Кривега, 1985; Іванова, Зайцева, 2014 etc.]. An analysis of petrographic and chemical composition of coal and its quality shows a relationship between the matter and petrographic composition, type of coal on reduction (Reduktionsfaktor) and its enrich- ment with sodium and chlorine, with the conditions for the accumulation of peat and subsequent transformation of organic matter, depending on the tectonic development of the region.

The position of the Western Donbass with coalmining regions is shown on the geological map with the zones of metamorphism of coals on the Paleozoic surface (Fig. 1). This map is the result of summary basin geological and cartographic works carried out in the late 1980s [Левенштейн, Спирина, 1991; Левенштейн, Спирина, Носова и др., 1991]. The gradations of metamorphic changes of coal on the map are presented in accordance with a three-level measurement system (to pre-inversion depth, vitrinite reflection index, a traditional set of coal quality indicators used in normative classification documents), which is reflected on the Standard scale of coal metamorphism, built in the middle of the 80's of the twentieth century [Levenshtein, Spirina, 1984]. 


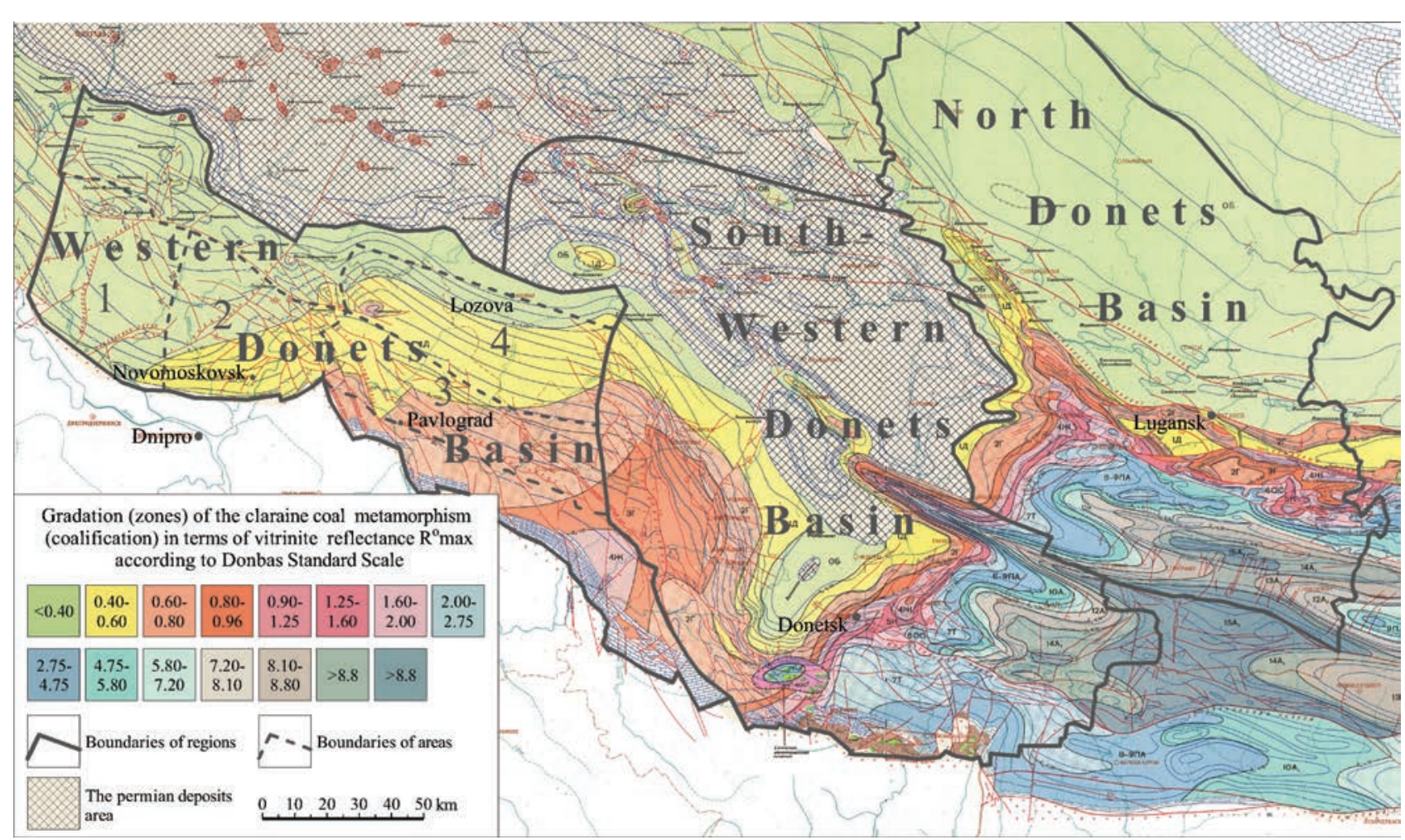

Fig. 1. The geological map with the metamorphism zones of coal over the Donbas Paleozoic surface [Левенштейн, Спирина1991; Левенштейн и др., 1991]

Areas: 1 - Petrykivsky; 2 - Novomoskovsky; 3 - Pavlogradsko-Petropavlivsky; 4 - Lozovsky

In the Western Donbas salt coals study included the description of thin sections in transmitted polarized light and definition of microcomponent composition of coals on the basis of 260 samples. The determination of vitrinite reflectance was performed on polished sections and polished sections-briquettes in oil immersion and in air (120 samples). It was investigated the quality of coal (technical analysis, elemental composition, chemical composition of the ash) and the composition of the aqueous extracts on sodium content (204 samples) and chlorine and sodium content (107 samples). The resulting material was multidisciplinary treated involving mathematical apparatus of statistics and modeling.

Previous investigators have quite fully identified the role of geotectonics in the formation of the geological structure and geostructural outline of the Western Donbas, but the question of the influence of the geotectonic regime on the conditions of the accumulation of peat and the formation of the matter and petrographic composition of coal, in particular saline, as well as on the geothermal conditions of the transformation of coal organics, resolved. The authors consider it expedient to provide additional materials on this subject.

\section{Geotectonic development}

The tectonic features of the Western Donbass are due to its location on the north-eastern slope of the Ukrainian crystalline shield, which, along the Mikhailovsko-Yurievsky fault, is attached to the southwestern part of the Dnipro-Donets Depression (DDD).

The history of the tectonic development is connected with the beginning of the formation of the Dono-Dnieper trough at the end of the Middle Devonian. During the Upper Devonian era, a thick stratum of continental-marine and effusive sediments accumulated in the Donetsk basin. During the Upper Devonian, a thick stratum of continental-marine and effusive sediments accumulated in the Donetsk basin. In the Western Donbass, only continental terrigenous clay deposits of low thickness (2-17 m) are known, which are preserved from erosion in depressions and in lowered blocks.

In Tournaisian age and the Early Visean times, carbonate rocks with a thickness of up to $600 \mathrm{~m}$ (suite $\mathrm{C}_{1}{ }^{1}$ ) were deposited on the northern slope of the Ukrainian Shield in conditions of shallow sea with variable contours. This stratum lies unconformably on the rocks of the crystalline basement or the Devonian. 
During the Late Visean and Serpukhovian the subsidence of the northern slope of the Ukrainian Shield and southern margin of DDD occurred as a result of the activation of tectonic regime. The polyfacial terrigenous strata with limestone and coal interlayers $\left(\mathrm{C}_{1}{ }^{2}-\mathrm{C}_{1}{ }^{4}\right.$ suites $)$ were formed in marshy lowland of the lagoon landscape. The Samarska Suite $\left(\mathrm{C}_{1}{ }^{3}\right)$ up to $800 \mathrm{~m}$ thick is the most coal-bearing.

The Sudeten phase of the Hercynian tectogenesis was manifested by the uplift of the southern margins of the Dono-Dnieper trough and the increase in the lowering of its central part. Differentiated movements began from the western part of the Ukrainian shield. This led to interruptions in sedimentation, which was recorded in the Western Donbas [Шульга и др., 2010], as well as in the DDD. Unlike the early Carboniferous in the Middle Carboniferous, further subsidence was more intensive, which led to more frequent marine transgressions. The terrigenous strata of rocks with thin interlayers of limestones and coals with a total thickness of 1400-1800 m (suites $\mathrm{C}_{2}{ }^{0}-\mathrm{C}_{2}{ }^{7}$ ) formulated mainly in coastal-marine conditions [ $[\mathrm{\Gamma eo}-$ логия..., 1963; Закономерности..., 1963; Шульга, 1981; Шульга и др., 1987; Вакарчук, Гавриш, 1991; Лукинов, Пимоненко, 2008 etc.].

During the Late Carboniferous and Early Permian the sedimentation regime remained close to that of the Middle Carboniferous. But the inversion of the Donets Basin at the Carboniferous-Permian boundary [Иванова, 2016; Привалов, 2002 etc.] resulted in erosion of the Upper Carboniferous deposits on the elevated places.

According to Lukinov V.V. and Pimonenko L.I. [Лукинов, Пимоненко, 2008], the Zaal phase of tectogenesis $\left(\mathrm{P}_{1}-\mathrm{P}_{2}\right)$ in the Western Donbass was accompanied by the of reverse faults formation and an increase in the fracture amplitudes spatially associated with submeridional deep faults.

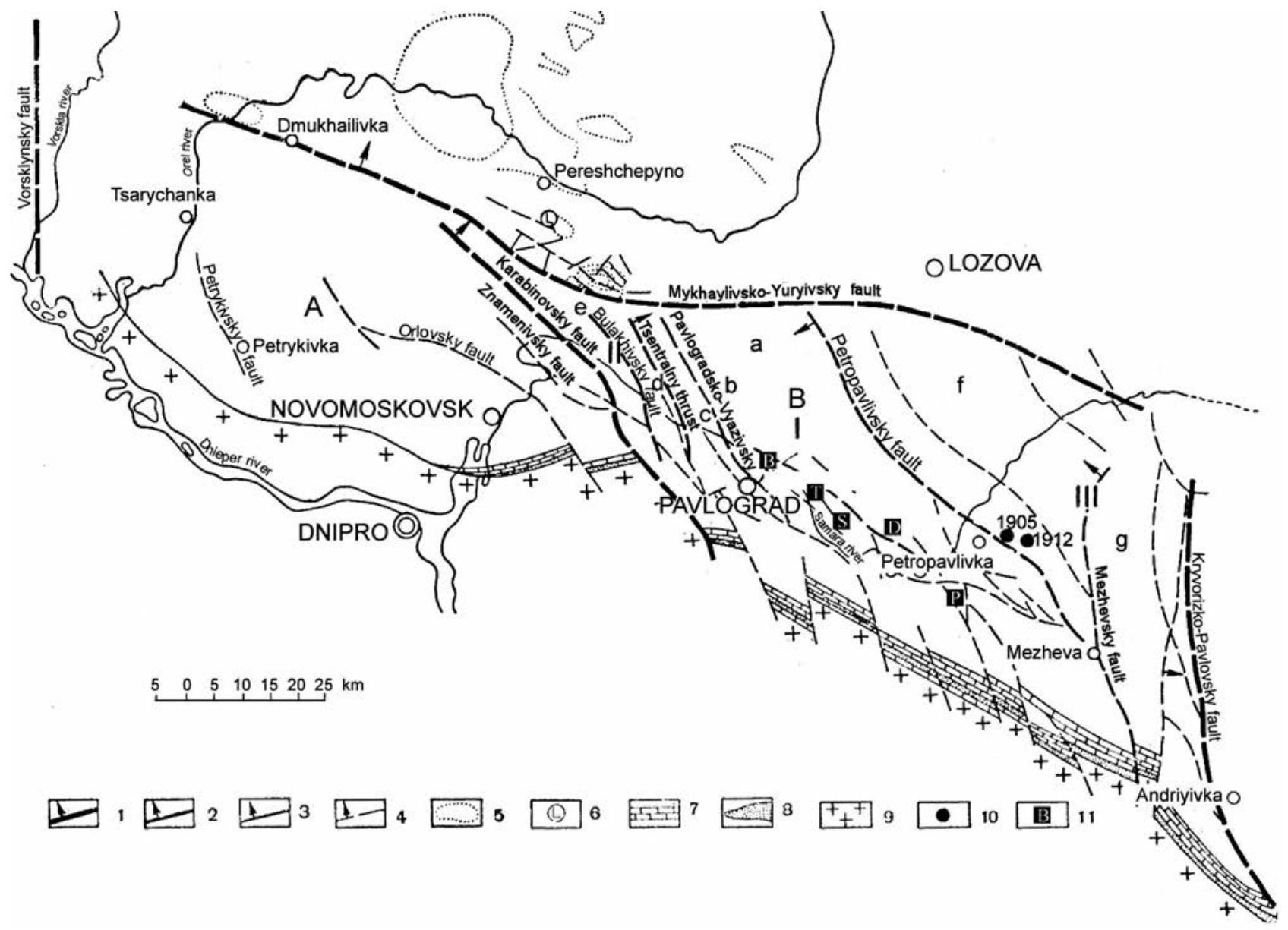

Fig. 2. Tectonic scheme of the Western Donbas [Закономерности..., 1963] with the points of sampling of coal samples Units of the first order: A - Prydniprovsky, B - Samarsky. Blocks of the second order:

I - Central; II - Western; III - Eastern. Blocks of the third order: a - Seredniy, b - Samarsky, c - Pavlogradsky, d - Bulakhivsky, e - Karabinovsky, $\mathrm{f}$ - Petropavlivsky, $\mathrm{g}$ - Mezhevsky. 1 - Fault of the first order; 2 - second order; 3 - third order; 4 - fourth order; 5 - domes; 6 - salt domes; 7 - limestone; 8 - Devonian; 9 - Precambrian; 10 - wells for calculating the erosion of Upper Paleozoic sediments; 11 - mines for which samples of coals for petrology study and for determination of their salinity have been selected: B - Blagodatna, T - Ternovska, S - Samarska, D - Dniprovska, P - Pershotravneva 


\section{Tectonic structure of the region}

The territory of the Western Donbass corresponds to the southern side of the DDD. The MikhailovskyYuryivsky deep fault (fracture) is a natural boundary with the DDD in the north, and the KrivorizkoPavlovsk deep fault (fracture) is a natural boundary with the South-Western Donbass in the northwest. Sedimentary rocks of the Carboniferrous form a monocline with a fall to the northeast at an angle of 3-12. The monoclinal is subdivided by sublatitudinal (Mykhaylivsko-Yuryivsky, Orlovsky et al.) and submeridional faults (Vorsklynsky, Karabinovsky, Tsentralny, Petropavlovsky, Kryvorizko-Pavlovsky et al.) of predominantly fault type, which form a complex step-block grid both over the crystalline rocks of the basement and so over the sedimentary rocks that overlap it. With large disturbances connected plikativnye dislocations in the form of gentle anticlinal uplifts, synclinal troughs, flexural flexural worries. The Karabinovsky block divides the monocline into the first order two large blocks: Prydniprovsky and Samara. Petrykovsky and Novomoskovsky coalbearing geological industrial areas are located within the Prydniprovsky block, which is bounded in the west by the Vorskla fault. The PavlogradPetropavlovsk geological and industrial region is located on the Samara block (Fig. 2).

Most of major tectonic disturbances, the formation of which began in early Paleozoic have inherited and consedimentation character of development. As a result, the entire sedimentary sequence, including the Permian sediments, is dissected by faults.

\section{Geothermic conditions}

Geothermc conditions of the region were determined by geotectonic regime. The values of recent geothermic gradients within the Western Donets Basin range from 2,3 to $4,0^{\circ} \mathrm{C} / 100 \mathrm{~m}$ [Геология..., 1963]. Earlier it was stated [Иванова, 2016; Іванова, Зайцева, 2014], that paleogeothermic gradients of Middle Carboniferous in the limits of the Southwest Donbass practically did not differ from the modern ones. This confirms the idea of M.L. Levenshtein [Геология..., 1963] about the comparability (proximity) of the values of modern geothermal gradients and paleogradients of the Donets Basin Paleozoic [Геология..., 1963]. Proceeding from this, it can be assumed that the paleogeothermal gradients of the carboniferous stratum of the PavlogradPetropavlovsk region did not exceed $4.0^{\circ} \mathrm{C} / 100 \mathrm{~m}$. The transition of gas to fat coals was fixed at a depth of $700 \mathrm{~m}$ in the wells 1905, 1012. According to A.V.
Ivanova (1992) calculations paleodepths boundary between gas and fat coals was $3,700 \mathrm{~m}$. This indicates that the Upper Paleozoic deposits with a thickness of about $3 \mathrm{~km}$ were eroded within the Eastern Block. These results coincide with the data of the scheme of paleotectonic reconstructions in the whole of the Donbas, according to research conducted by Yu.V. Nagorny and V.V. Nagorny (1976) for Carboniferous and Lower Permian deposits.

Modern geothermal anomalies established on the territory of the Pavlograd-Petropavlovsk and Lozov regions of the Western Donbas [Пимоненко и др., 1992] have not affect on the degree of catagenetic changes in the carboniferous stratum, since the heat flux and temperatures in the Earth's crust during the Hercynian tectogenesis period were significantly higher than in the period Cimmerian and Alpine tectonomagmatic activation [Кутас, Цвященко, 1993].

\section{Peat accumulation conditions. Coal-bearing capacity}

Coal-bearing capacity of the Western Donbas is confined to the terrigenous strata of the Lower and Middle Carboniferous. According V. Shulga [Шульга, 1981], the Lower Carboniferous marsh-lagoon coalbearing formation, is subdivided into three subformations. Lower poor coal bearing marsh-transgressive subformation lies in the lower part of $\mathrm{C}_{1}{ }^{2}$ suite up to the limestone $\mathrm{B}_{10}$. It is composed of sandstones and argillites with thin limestone and coal interlayers. The middle high coal bearing, regressive-transgressive marsh-lagoon subformation lies in the upper part of the $\mathrm{C}_{1}{ }^{2}$ suite up to limestone $\mathrm{C}_{5}$ of $\mathrm{C}_{1}{ }^{3}$ suite. It is represented by siltstone and argillite strata with numerous coal seams and thin clayey limestone interlayers. Upper poor coal-bearing marsh-marine subformation of the upper part of the $\mathrm{C}_{1}{ }^{3}$ suite (up to $\mathrm{D}_{1}{ }^{2 \mathrm{c}}$ limestone of the $\mathrm{C}_{1}{ }^{4}$ suite), is composed of the mudstone and sandstone strata with limestone interlayers and thin coal seams (Fig. 3).

The high coal bearing subformation that developed mainly in sustainable lagoon environment contains deposits of $\mathrm{C}_{1}{ }^{2}$ suite $\left(b_{6}-b_{8}\right.$ seams of 0.45-0.75 m) and $\mathrm{C}_{1}{ }^{3}$ suite $\left(c_{0}-c_{17}\right.$ seams). The $c_{1}$, $c_{5}-c_{11}$ seams with average thickness of $0.7-0.8 \mathrm{~m}$ have industrial significance. The depth of the seams occurrences increases from $100 \mathrm{~m}$ to $1500 \mathrm{~m}$ northward. The majority of seams are categorized as thin, they are characterized by constant occurrence over the area, but unstable thickness. Seams tops and soils are mainly composed of argillites and siltstones. 

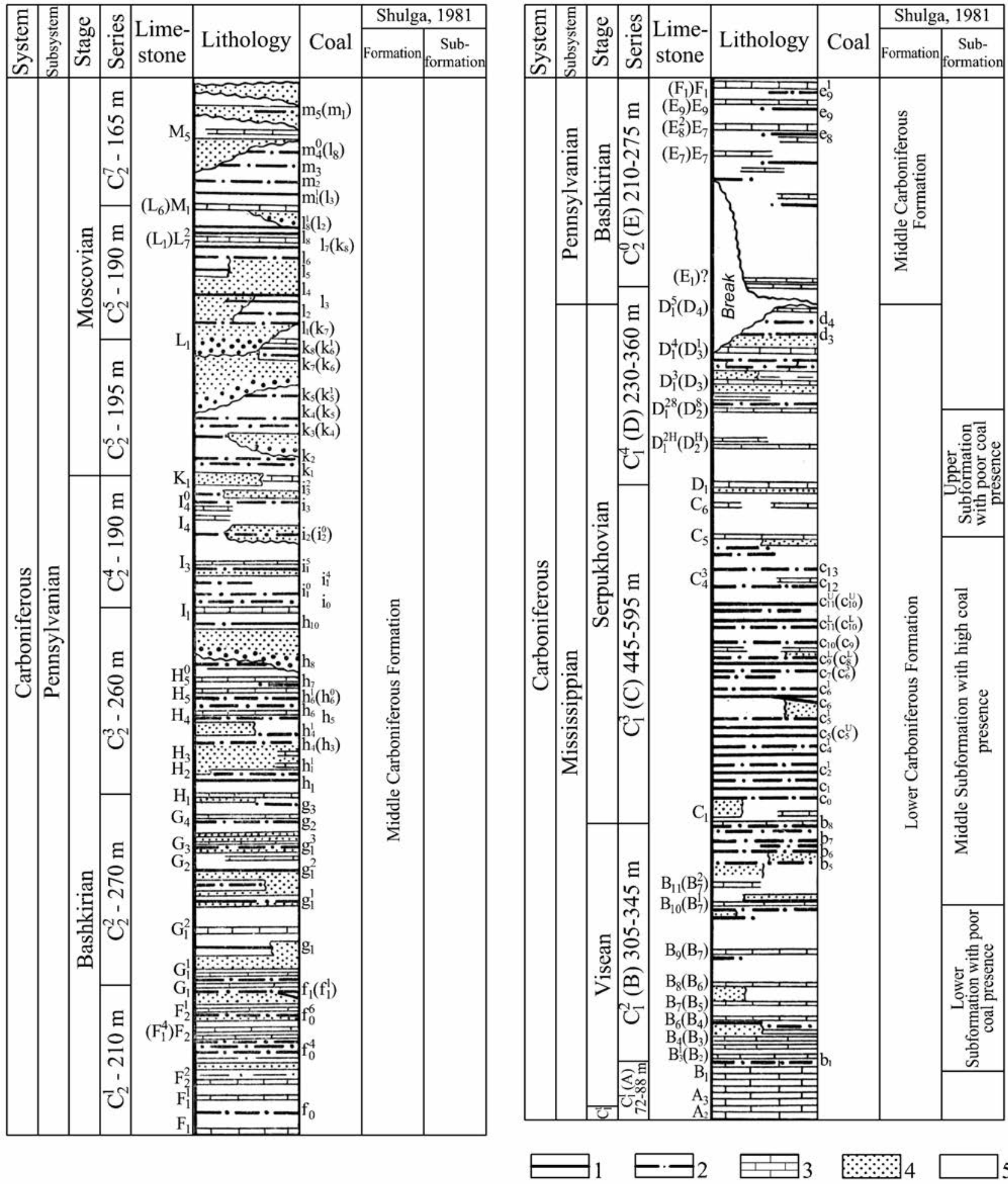

Fig. 3. The section of Lower and Middle Carboniferous coal-bearing formations [Закономерности..., 1963; Шульга, 1981; Тетерюк, 1984; Стратиграфія..., 2014]

1 - working coal bed; 2 - unworkable coal bed; 3 - limestones; 4 - sandstones; 5 - mudstones, siltstones

Within the seams are interlayers of argillites (from 0.03-0.05 to $0.20 \mathrm{~m})$ and kaolinite $(0,02-0.03 \mathrm{~m})$. Kaolinite interlayers have been identified in coal seams $c_{1}, c_{6}, c_{7}, c_{9}{ }^{l}, c_{11}$ [Лескевич, Савчук, 1961; Черновьянц, 1992]. The seams have a simple and a complex structure. The complex structure is the result of the splitting due to uneven subsidence of peat accumulation area in result of the tectonic processes. Sometimes splitting of layers is associated with the paleorivers activity [Шульга, 1981]. 
In the Middle Carboniferous the sedimentation, according to the calculation of accumulation rates, was almost 2 times faster than in the Early Carboniferous. The sedimentation took place in the estuaries parts of a river valleys in subordinated lagoon environment [Феофилова, Левенштейн, 1963], which were changing into shallow-marine and marine ones due to the intensity of marine transgressions.. In Middle Carboniferous deposits $\left(\mathrm{C}_{2}{ }^{0}-\mathrm{C}_{2}{ }^{7}\right.$ suites) there are up to 70 coal seams [Закономерности..., 1963]. Coal seams $f_{1}\left(\mathrm{C}_{2}{ }^{1}\right.$ suite $), g_{1}{ }^{3+4}\left(\mathrm{C}_{2}{ }^{2}\right.$ suite), $h_{5}\left(\mathrm{C}_{2}{ }^{3}\right.$ suite) reach the working capacity in the northwest. The roof and soil of coal seams are mainly composed of mudstones and siltstones. In the strata are observed interlayers of argillite, coal argillite. Investigations [Черновьянц, 1992] revealed the kaolinite interlayers in the coal seams $g_{1}^{4}$ and $g_{2}$ of the $\mathrm{C}_{2}{ }^{2}$ suite. The thickness of such layers is $0.02-0.20 \mathrm{~m}$. The structure of the layers is often simple and its lie at depths of 200 to $1000 \mathrm{~m}$.

The kaolinite interlayers (tonsteins) have been indentifisd in the Middle Carboniferous deposits practically throughout the entire Donbass region [Узиюк, 1992; Черновьянц, 1992; Зарицкий, 2012]. The wide spreading of the tonsteins over the area of the basin, the synchronicity of the formation, their mineralogical and petrographic features prove its a volcanogenic origin and the possibility of using them as marking horizons. Most likely the delivery of lava ash material was from the North Caucasus. The presence of a powerful volcanism in the early and middle Carboniferous is evidenced by the widespread development of volcanogenic rocks in the Carboniferous deposits of the Caucasus Advanced Range [Геология..., 1968]. There were no centers of active volcanic activity, which could serve as a source of ash material on the territory of Ukraine in the Caroniferous [Гойжевский и др., 1977].
Calculations of the ratio of continental and marine facie in the Lower and Middle Carboniferous deposits showed that in the Middle Carboniferous epoch a greater influence of marine conditions was observed. According to V.F. Shulga [Шульга, 1981], in the Lower Carboniferous coalbearing formation, marine sediments average $44 \%$. The content of the marine facies of the $\mathrm{C}_{2}{ }^{6}$ and $\mathrm{C}_{2}{ }^{7}$ suites of the middle Carboniferous of the southwestern Donbas is on average 54\% [Тимофеев, 1953].

The Leifman-Vassoevych coefficient calculated according to the elemental composition of the organic matter was used to refine the Lower and Middle Carboniferous coal-bearing formation environments. For the Lower Carboniferous this ratio averages 0.45 in the Novomoskovsky area and 0.49-0.55 in Pavlogradsko-Petropavlivsky area. For the Middle Carboniferous in PavlogradskoPetropavlivsky area (Uspenivka sites) the ratio is 0.48 . These data prove that during the early and middle Carboniferous peat formed from the remnants of vegetation of terrestrial origin under the influence of marine conditions [Вассоевич, Лейфман, 1979].

Paleogeographical environments during the Early and Middle Carboniferous caused paralic type of this accumulation, which contributed to the development of salt coal in the Western Donets Basin [Иванова, Кривега, 1985; Угленосные..., 1990].

\section{The conditions of coal petrographic composi- tion formation}

Geotectonic regime, characterized by different rates of subsidence of peat accumulation area during the early and middle Carboniferous, largely have caused a different petrographic composition of coal (Table 1).

Table 1. Petrographic composition of Lower and Middle Carboniferous coals (averaged data, \%)

\begin{tabular}{|c|c|c|c|}
\hline \multirow{2}{*}{ Area } & \multicolumn{3}{|c|}{ The composition of coal by microcomponent groups } \\
\cline { 2 - 4 } & $\mathrm{Vt}$ & $\mathrm{I}$ & $\mathrm{L}$ \\
\hline \multicolumn{4}{|c|}{ Lower Carboniferous } \\
\hline Petrykivsky & 52 & 24 & 24 \\
\hline Novomoskovsky & 54 & 24 & 22 \\
\hline Pavlogradsko-Petropavlivsky & 56 & 23 & 22 \\
\hline \multicolumn{5}{|c|}{ Middle Carboniferous } \\
\hline Petrykivsky & 78 & 10 & 12 \\
\hline Novomoskovsky & 80 & 10 & 10 \\
\hline
\end{tabular}


In the Early Carboniferous epoch, peat accumulation occurred in the swamps and forestswamps, flowing, periodically drained, with a limited intake of terrigenous material in a warm humid climate on the lagoon seaside coast, which was subjected to periodic transgressions of the shallow sea. The main representatives of plant associations of bogs were _grassy Plauniforms (Selaginella) and Pteridosperms, less often Arthropods. Such conditions contributed to the accumulation of coals with low and medium contents of vitrinite and strongly decomposed plant material.

In the Middle Carboniferous, the formation of forest and forest-fens flooded bogs occurred mainly in a more stagnant regime on the coastal-marine lowland, which was subjected to frequent transgesses of the deeper sea. The watering of the marshes increased laterally from land to sea. Flora, in comparison with the early Carboniferous, was enriched by a large number of new species. The treelike Plauniforms (Lycopsida), Pteridosperms, Arthropods (Sphenopsida) and seed Ferns (Pteropsida) were the starting material for the subsequent formation of vitrinite coals with sufficiently good preservation of plant structure [Феофилова, Левенштейн, 1963; Новик, 1974; Тетерюк, 1984; Егоров, 1985; Тимо-
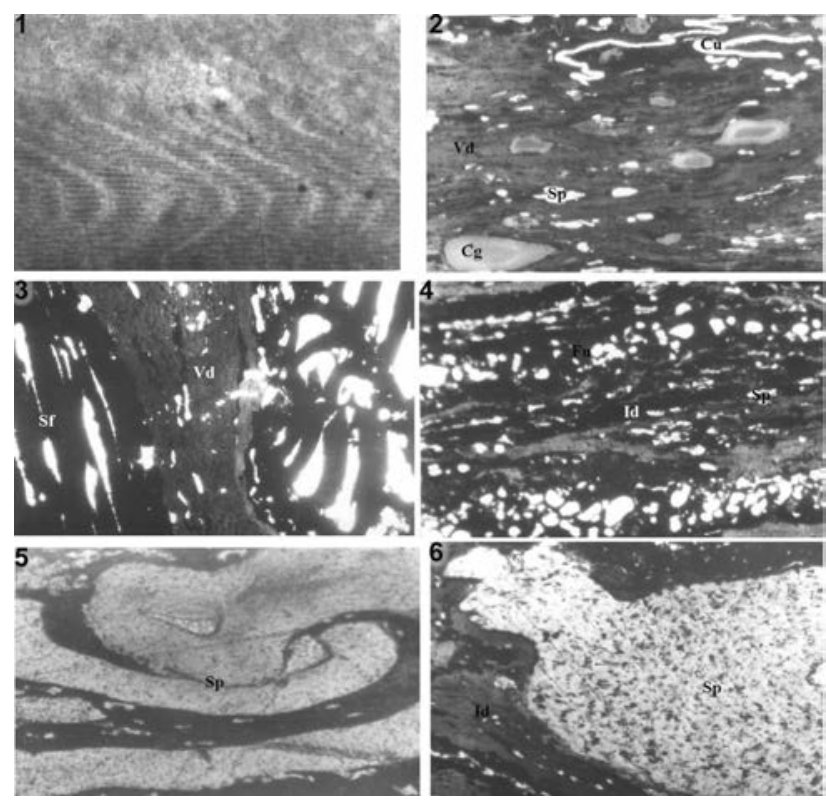

Fig. 4. Microphotographs of coals have been carried out in transmitted light, $x 146$. Macerals of the Lower Carboniferous coals of the Western Donets Basin

1. Telinite. Mine Pershotravneva, seam $c_{l}$. 2. Vitrodetrinite (Vd), (mio)sporinite $(\mathrm{Sp})$, corpogelinite $(\mathrm{Cg})$, cutinite $(\mathrm{Cu})$. Mine Ternovska, seam $c_{4}{ }^{1}$. 3. Semifusinite (Sf) and vitrodetrinite (Vd). Mine Ternovska, seam $c_{4}{ }^{l}$. 4. Fusinite (Fu), (mio)sporinite (Sp) in inertodetrinite (Id). Mine Blagodatna, seam $c_{8} .5$. (Mega)sporinite (Sp). Mine Dniprovska, seam $c_{10}$. 6. Microsporangia (Sp). Mine Blagodatna, seam $c_{8}$ феев, 2006; Шульга и др., 2010]. A similar upward trend in the formation of coals of dendritic form coal from suites $\mathrm{C}_{1}{ }^{3}-\mathrm{C}_{1}{ }^{4}$ to $\mathrm{C}_{2}{ }^{5}-\mathrm{C}_{2}{ }^{6}$ is observed for Southern and Southwestern Donbas [Закономерности..., 1963; Sachsenhofer et al., 2003].

In accordance with ICCP System 1994 [International..., 2005] organic coal microcomponents are subdivided into three groups: vitrinite, inertinite, liptinite (Fig. 4, 5).

Vitrinite. The unequal initial material and various processes of its accumulation and transformation influenced the characteristics of the components of the vitrinite group of the Lower and Middle Carbon coals: quantity, the ratio of structural and structureless components, and the difference in color shades.

The number of components of the vitrinite group in the coals of the Lower Carboniferous does not on average exceed $52-58 \%$, sometimes in the lower part of the layers the amount of vitrinite increases to $80-85 \%$. The vitrinized components are represented mainly by vitrodetrinite, collothelinite. A characteristic feature of this group is the presence of rare large fragments of telinite formed from periderm, tissues of sporulation organs. The color of the components is more often reddish-brownish. A slight
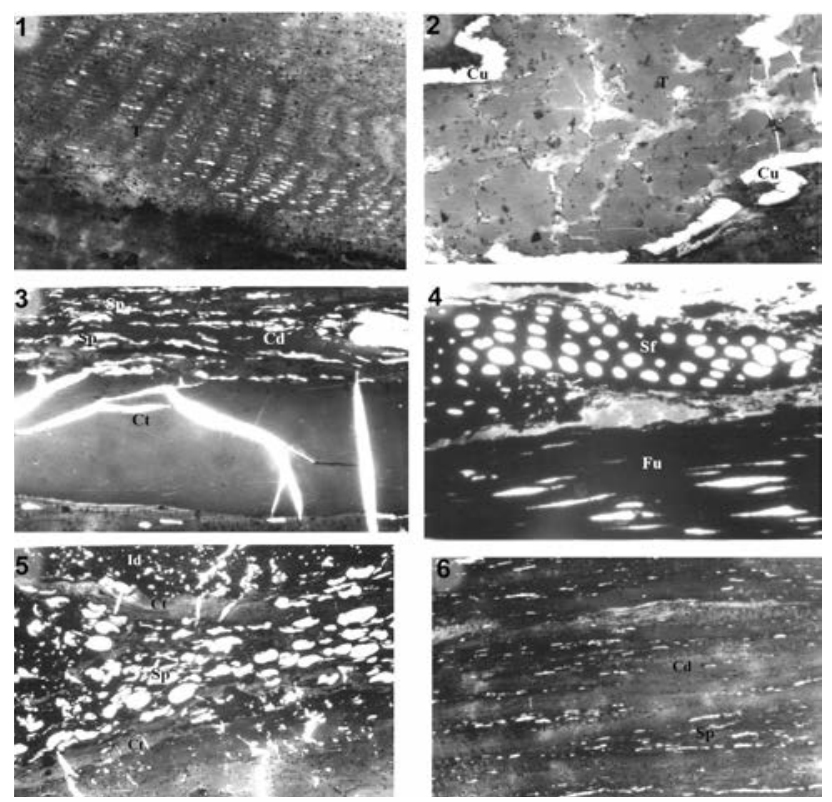

Fig. 5. Microphotographs of coals have been carried out in transmitted light, $\times 146$. Macerals of the Middle Carboniferous coal of Western Donets Basin

1. Telinite (T), Lozovsky area, b/h 11086 , seam $l_{8}$. 2. Telinite $(T)$, cutinite (Cu), Lozovsky area, b/h 11098, seam $l_{8}$. 3. Collotelinite $(\mathrm{Ct})$, collodetrinite $(\mathrm{Cd})$ and (mio)sporinite $(\mathrm{Sp})$, Lozovsky area, $\mathrm{b} / \mathrm{h} 11071$, seam $l_{6} .4$. Fusinite (Fu) and semifusinite (Sf), Lozovsky area Zapadno-Uspenovsky site, b/h 14707, seam $\mathrm{g}_{I} .5$. Collotelinite (Ct), (mio)sporinite (Sp) and inertodetrinite (Id), Livensky-Myhaylivsky area, b/h 24, seam $l_{2} .6$. Collodetrinite (Cd) and (mio)sporinite (Sp), Lozovsky area, b/h 11094, seam $l_{2} \times 57,5$ 
increase of vitrinite in the Lower Carboniferous coals southeastwards (from Petrykivsky to Pavlogradsko-Petropavlivsky areas) should be noted. This corresponds to marine facies increase [Шульга, 1981] in deposits of this age.

In the coals of the Middle Carboniferous, the vitrinite group components amount to $78 \%$, with predominance of vitrodetrinite, collotellinite. Simultaneously, in comparison with the coals of the Lower Carboniferrous, the amount of structural components increases. They are represented by small fragments formed by periderm, xylem, parenchyma. The color of the components is bright, red or orangeish-reddish.

Inertinite. This group combined semifusainized and fusainized components, the amount of which in the Lower Carboniferous coals on average is $20-30 \%$, reaching $55 \%$ in coal of low vitrinite content. Often there is semifusinite and fusinite, inertodetrinite, and less macrinite and funginite (sclerotinite). The fusainized components in the Middle Carboniferous coals are $4-16 \%$. They are mainly fusinite, semifusinite, inertodetrinite, funginite.

Liptinite plays an important role in the Lower Carboniferous coals. The average content of components is $18-23 \%$, in spore coal of low vitrinite content it rises up to $50 \%$. The most common is sporinite, represented by yellow mio- and megasporinite. In Middle Carboniferous coals the content of lipoid components generally does not exceed $17 \%$. This groups the light yellow miosporinite dominates, there is a small amount of cutinite and resinite. The presence of alginite is characteristic of the Lower Carboniferous coals. They are represented by the light yellow talomo-alginite and colo-alginite.

Mineral components of coals are quite diverse. They were brought in during peat accumulation of plant material (alothigenic minerals) or formed by diagenetic and katagenetic processes (authigenic minerals). Inorganic components are observed as lenticules, individual grains and clusters, scattered material, pseudomorphs after plant tissues, cracks or cell cavities fills. In the Lower Carboniferous coals the most common is pyrite, marcasite, calcite, quartz, clay formations, kaolinite. In the Middle Carboniferous coals the most common are pyrite, kaolinite, clay material, calcite, quartz and chalcedony.

Petrographic types of coal are distinguished according to the content of vitrinite: clarains - coal with high vitrinite content (vitrinite $>80 \%$ ), durainclarains - coal with moderately high vitrinite content (vitrinite $60-80 \%$ ), clarain-durains - coal of medium vitrinite content (vitrinite 40-60\%), durains - coal of low vitrinite content (vitrinite $<40 \%$ ) [Бердюкова и др., 1964; International..., 2005].

Quantitative petrographic analysis has shown that in the Lower Carboniferous coals of Western Donets Basin clarain-durainous and durain coals dominate (43\% and $27 \%$ ), less common are durainclarain (18\%) and clarain (12\%). Clarain and durain-clarain are observed mainly in the lower parts of coal seams. Sometimes cannel and boghead-cannel coal occur in the upper parts of coal seams.

The Middle Carboniferous humic coals are mainly represented by clarain $(50 \%)$ and durainclarain $(35 \%)$. Clarain-durain is observed $(15 \%)$ in the form of thin lenticular interlayers.

Except of coal types based on the petrographic composition the coal types were identified by reduction (Reduktionsfaktor).

The authors of the concept of reduction degree of coal are V.V. Vidavski, N.Ya. Ryabokoneva [Видавский, Рябоконева, 1941]. Reduction degree of coals is determined by the qualitative difference of vitrinite in the coals of the same degree of metamorphism, which is associated with a redox peat bog environment. At the same degree of metamorphism the "reduced" coal gives more volatile, contains more hydrogen and carbon, less oxygen, differs somewhat higher ash and sulfur, characterized in comparison with weakly "reduced" coal by the less degree of decomposition of organic matter, more bright color and less reflectance index of vitrinite. Geotectonic factor plays a key role in the formation of coals of different reduction degree. It is manifested in peat subsidence rate and determines the facies environment of peat accumulation [Власов, Иванов, 1968; Тимофеев, 2006; Вялов, 2006 etc.].

Thus, during the Lower Carboniferous the coals of transitional and poorly reduced type were distributed. They were characterized by vitrinite of brownish-reddish color, by the presence of a large amount of vitrodetrinite and collodetrinite, i.e. almost complete decomposition products. It should be noted that the higher Leifman-Vassoevych [Вассоевич, Лейфман, 1979] coefficient obtained for the Lower Carboniferous coal of Pavlogradsko-Petropavlivsky area (see above) compared with Novomoskovsky area coal, probably confirms a higher degree of its reduction. The Middle Carboniferous coals are more reduced, their vitrinite components have bright yellowish-red color and better preservation of plant material structure. 


\section{Some features of quality of coals}

The quality of coal depends on the petrographic composition, the type by reduction ratio and the degree of coalification. The degree of coalification varies from the brown stage to the gas one in the southeast direction as the increasing of the Carboniferous strata thickness. The vitrinite reflection indexes respectively increase in the direction from Petrykivsky area $(0.40-0.49 \%)$ to the PavlogradPetropavlovsk one $(0.75-0.84 \%)$ for both the Lower and Middle Carboniferous [Закономерности..., 1963; Геология..., 1963; Иванова, Кривега, 1985; Угленосные..., 1990] (Table 2).

For low-reduced coals of the Lower Carboniferous, a smaller content of ash, hydrogen, volatile substances and sulfur and a greater oxygen content are characteristic. For the reduced isometamorphic coals of the Middle Carboniferous, the listed quality indices have higher values only the oxygen content and reflection rate become smaller.

According to N.A. Ignatchenko [Угленосные..., 1990], low ash content in Lower Carbonaceous coal is associated with their formation on a vast coastal plain. On its periphery was a wide belt of forest peat bogs. This belt was the place of the main unloading of sluggish river flows.
A higher yield of resin in semi-coking is obtained from coals of the Lower Carboniferous, in comparison with coals of Middle Carboniferous, is associated with an increased content of liptinite components.

In the Western Donbas and in the adjacent areas of the DDD the so-called "salt coals" are widespread in the Lower and Middle Carboniferous. The main feature of "salt coals" is the release of significant amounts of sodium and chlorine, which was the result of seawater influence during accumulation of the peat bog [Иванова, Кривега, 1985; Иванова, 2016].

On the basis of the data obtained, the ash from coals of the Western Donbass is characterized by a regular decrease in the sodium content in the direction east-southeast as the degree of coalification increases. The saline coals of the most productive suite of the $\mathrm{C}_{1}{ }^{3}$ suite are most studied. The ash of these coals contains from $8.5 \% \mathrm{Na}_{2} \mathrm{O}$ in the Petrikov district to $1.5 \%$ and less one in the eastern part of the Pavlograd-Petropavlovsk area. The most interesting are the coals of the Novomoskovsk region. According to the main qualitative indicators, they are a valuable energy source, but they are not used because of the high content of sodium and chlorine in them. The content of sodium oxide in

Table 2. Average quality indices of the Lower and Middle Carboniferous coals of the Western Donets Basin

\begin{tabular}{|c|c|c|c|c|c|c|c|c|c|c|}
\hline \multirow{2}{*}{ Area } & \multicolumn{2}{|c|}{$\begin{array}{c}\text { Coal metamorphism } \\
\text { phase }\end{array}$} & \multirow{2}{*}{$\mathrm{R}^{\mathrm{o}}, \%$} & \multirow{2}{*}{$\mathrm{A}^{\mathrm{d}}, \%$} & \multirow{2}{*}{$\mathrm{V}^{\text {daf }}, \%$} & \multirow{2}{*}{$\mathrm{S}_{\mathrm{t}}^{\mathrm{d}}, \%$} & \multirow{2}{*}{$\begin{array}{l}\mathrm{Q}_{\mathrm{s}}^{\mathrm{daf}}, \\
\mathrm{MJ} / \mathrm{kg}\end{array}$} & \multirow{2}{*}{$\mathrm{C}^{\mathrm{daf}}, \%$} & \multirow{2}{*}{$\mathrm{H}^{\mathrm{daf}}, \%$} & \multirow{2}{*}{$\begin{array}{l}\text { Resin } \\
\text { yield, } \\
\%\end{array}$} \\
\hline & $\begin{array}{c}\text { GOST } \\
21489-76\end{array}$ & $\begin{array}{c}\text { ISO } \\
11760: 2005\end{array}$ & & & & & & & & \\
\hline \multicolumn{11}{|c|}{ Lower Carboniferous } \\
\hline Petrykivsky & $0_{3}$ & $\begin{array}{l}\text { Subbitumi- } \\
\text { nous }\end{array}$ & $\begin{array}{l}0,40- \\
0,49\end{array}$ & 14 & 45 & 1,6 & 29,9 & 74 & 5,2 & 10,5 \\
\hline Novomoskovsky & I & $\underset{\mathrm{D}+\mathrm{C}}{\text { Bituminous }}$ & $\begin{array}{c}0,50- \\
0,64\end{array}$ & 10 & 44 & 1,9 & 30,9 & 76 & 5,3 & $\begin{array}{l}8,4- \\
14,7\end{array}$ \\
\hline $\begin{array}{l}\text { Pavlogradsko- } \\
\text { Petropavlivsky } \\
\text { (western part) }\end{array}$ & I-II & $\underset{\mathrm{C}}{\text { Bituminous }}$ & $\begin{array}{c}0,65- \\
0,74\end{array}$ & 9 & 41 & 1,6 & 33,4 & 80 & 5,3 & - \\
\hline $\begin{array}{l}\text { Pavlogradsko- } \\
\text { Petropavlivsky } \\
\text { (eastern part) }\end{array}$ & II & $\underset{\mathrm{C}}{\text { Bituminous }}$ & $\begin{array}{c}0,75- \\
0,84\end{array}$ & 8 & 40 & 1,9 & 34,4 & 83 & 5,4 & $\begin{array}{l}11,0- \\
19,0\end{array}$ \\
\hline \multicolumn{11}{|c|}{ Middle Carboniferous } \\
\hline Petrykivsky & $0_{3}$ & $\begin{array}{l}\text { Subbitumi- } \\
\text { nous }\end{array}$ & $\begin{array}{c}0,40- \\
0,49\end{array}$ & 21 & 45 & 4,6 & 27,7 & 69 & 5,5 & - \\
\hline Novomoskovsky & $0_{3}-\mathrm{I}$ & $\begin{array}{c}\text { Subbitu- } \\
\text { minous - } \\
\text { bituminous } \\
\text { D }\end{array}$ & $\begin{array}{l}0,40- \\
0,60\end{array}$ & 18 & 45 & 5,1 & 29,3 & 71 & 5,5 & 10,0 \\
\hline
\end{tabular}


the ash of coals of the Lower Carboniferrous varies from $\%$ to $18.3 \%$. The content of sodium oxide in the ash of coals of the Middle Carboniferrous varies from severa $1 \%$ to $15 \%$.

The content of $\mathrm{Na}_{2} \mathrm{O}$ on dry coal of the most studied of seam $c_{1}$ of the Novomoskovskoy deposit varies from 0.3 to $1.5 \%$ and proves the uneven salinity of the coal caused by heterogeneity of geochemical conditions of peat accumulation [Иванова, Кривега, 1985].

The eastern boundary of the distribution of salty coals is in the western part of the PavlogradPetropavlovsk region. A significant decrease in the amount of $\mathrm{Na}_{2} \mathrm{O}$ in the eastern part of the Pavlograd-Petropavlovsk region could be caused not only by an increase in the degree of coalification, but also by the uplift of the Eastern Bloc and activation of the hydrogeological regime, which contributed to the removal of metamorphic products and the desalting of coals. The average $\mathrm{Na}_{2} \mathrm{O}$ content with 0.08 and $0.05 \%$ in the gas coals of the $c_{1}$ of Samara and Pershetravnev mines is illustration of this thesis [Иванова, Кривега, 1985].

\section{Conclusions}

The regime of geotectonic development of the Western Donbas formed the conditions of the peat accumulation, the change of phytocoenoses, the nature of the transformation of organic matter, pre-inversion depth of coal seams, the geothermal conditions of the region and the degree of coalification of organic matter. These factors have determined of peculiarities of composition and quality of coal. In the conditions of the warm humid climate, the geotectonic evolution of the Western Donbass was different in the Early and Middle Carboniferous.

In the Early Carboniferous there was accumulation of turf in the tumultuous and forest-boggy marshes, flowing, periodically drained, with a limited supply of terrigenous material on the seaside lagoon coast, undergoing periodic transgressions of the sea. The main representatives of plant associa-

\section{References}

Berdiukova M.D., Inosova K.I., Ishchenko A.M., Kolomeitseva A.K., Lifshitz M.M., Pazukhina D.K., Sharayeva L.N., Shirokov A.Z., 1964. Atlas of the Lower Carboniferous coals of Donets basin. Moscow: Nauka, 205 p. (in Russian).

Vakarchuk G.I. Gavrish V.K., 1991. Breaks and unconformity in the Paleozoic section of Dnieper-Donets depression. Geologichnyy zhurnal, № 1 (256), p. 119131 (in Russian). tions of marshlands were herbaceous Planuniform (Selaginella) and Pteridosperms. Such conditions contributed to the formation of coals with low and medium vitrinite content, highly decomposed plant material.

In the Middle Carboniferous, the formation of forest and forest-fens flooded bogs occurred mainly in a more stagnant regime on the coastal-marine lowland, which was subjected to frequent transgresses of the deeper sea. The watering of the marshes increased laterally from land to sea. Flora, in comparison with the Early Carboniferous, was enriched by a large number of new species. Tree shapes Planuniform (Lycopsida), Pteridosperm and also Arthropods (Sphenopsida) and seed Ferns (Pteropsida) were the initial material for the subsequent formation of vitrinite coals with sufficiently good preservation of plant structure.

The parameters of the quality of coals of both Lower and Middle Carboniferous are dependent on the petrographic composition, type of reduction ratio and degree of coalification (metamorphism), which increases in the east direction.

The characteristic feature of coals is salinization as a result of the influence of sea water on the organic matter during peat formation. Salinity of coals decreases with increasing degree of coalification.

Hercynian tectogenesis led to erosion of Upper Carboniferous - Lower Permian sediments with a thickness of about $3 \mathrm{~km}$. Activation of the hydrogeological regime as a result of tectogenesis was an additional factor of desalting of coals.

\section{Acknowledgements}

We express our sincere gratitude to Professor Dr. Ralph Littke for his review of the manuscript and very important comments that helped to more clearly formulate our views on the topic under discussion. We are deeply grateful to Dr. Tamara Nemirovskaya for important and productive discussions. We also thank Mr. Victor Gavriltsev for help and technical support in preparing the computer version.

Vassoevych N.B., Leifman I.E., 1979. On the estimation of the proportion of hydrogen, which determines the oil source potential of organic matter. In: Oil source rocks and the principles of their diagnosis. Moscow: Nauka, p. 36-46 (in Russian).

Vidavski V.V., Ryabokoneva N.Ya., 1941. Donetsk coals organic mass due to their coking. In: Geologicalcoal-chemical map of the Donets Basin. Iss. 5. KharkovMoscow: Ukrgostopizdat, p. 432-514 (in Russian). 
Vlasov V.M., Ivanov G.A., 1968. Determination of the degree of coal reduction according to the lithological data. In: Issues of coal metamorphism and host rock epigenesis. Leningrad: Nauka, p. 45-50 (in Russian).

Vyalov V.I., Gurevich A.B., Kosinsky V.A., 2006. Quality of coal. In: Petrological atlas of fossil organic matter of Russia. St.-Petersburg: VSEGEI Publ., p. 29-72 (in Russian).

The geology of coal deposits and costimable slates of USSR, 1963. Vol. 1. Moscow: Gosgeoltechszdat, 1210 p. (in Russian).

The geology of USSR. The Nothern Caucasus, 1968. (Eds.: V.L. Androoshchuk, A.Y. Dooinskiy, V.E. Hain). Vol. 9, pt. 1. Moscow: Nedra, 760 p. (in Russian).

Gojzhevsky, A.A., Naumenko, V.V., Skarzhinsky, V.I., 1977. The tectono-magmatic activization regions of Ukraine. Kyiv: Naukova Dumka, 120 p. (in Russian).

Yegorov A.I., 1985. Carboniferous fuels and shale formations of the European part of the USSR. Rostovna-Donu: Rostov. University Publ., 192 p. (in Russian).

The regularitries of the coalaccumulation on the Western Donbas territory, 1963. (Ed. A.Z. Shirokov). Moscow: Gosgortekhizdat, 452 p. (in Russian).

Zaritsky P.V., 2012. Intercoal interlayers (tonshtein or kaolinite) are products of volcanic ash transformation in the process of coalification (on the example of Donbass). Diagnosis of volcanic products in sedimentary strata:Proceeding Ros. sovshch. with intern. participation. Syktyvkar, IG Komi Scientific Center of the Ural Branch of the Russian Academy of Sciences, p. 121-123 (in Russian).

Ivanova A,V., 1985. The geologic - genetic and petrochemical factors of saltinity of coals of the Western Donbas. Geologichnyy zhurnal, № 3 (222), p. 25-33 (in Russian).

Ivanova A.V., 1992. Data processing technique of vitrinite thermometry for paleogeothermal and paleotectonic reconstructions. Geologichnyy zhurnal, № 6 (267), p. 32-36 (in Russian).

Ivanova A.V., 2016. Genesis and evolution of highchlorine coals of Ukraine and use problems: dis. ... doktor geol. nauk / Institute of Geological Sciences of NAS of Ukraine. Kyiv, 40 p. (in Ukrainian).

Ivanova A.V., Krivega T.A., 1985. Salt coal of Western Donets Basins. Kiev: Naukova Dumka, 124 p. (in Russian).

Ivanova A.V., Zaitseva L.B., 2014. The role of geodynamics in the peat accumulation and coal materialpetrographic composition formayion in Western Donbas. Tektonika i stratigrafiya, iss. 41, p. 40-48 (in Ukrainian).

Kler V.R., Zharov Yu.N., Slivinskaya I.I., 1988. On the distribution of sodium and potassium in the coals. Doklady AN SSSR, vol. 298, № 4, p. 936-938 (in Russian).
Kutas R.I., Tsvyashchenko V.A., 1993. The heat processes in geological history of Donbas. Geofizichesky zhurnal, vol. 15, № 2 (21), p. 42-53. (in Russian).

Levenstein M. L., Spirina O.I., 1991. The explanatory note to the set of maps of the coal metamorphism of Donbas in scale 1:500 000 (on the Paleozoic surface, on the levels: $-400 \mathrm{~m},-1000 \mathrm{~m},-1600 \mathrm{~m}$ and on the structural plans of coal seams $c_{1}{ }^{6}$ and $k_{5}$ ). Kiev: GlavKGU "UkrGeologiya", 104 p. (in Russian).

Levenshtein M.L., Spirina O.I., Nosova K.B., Dedov S.V., Dubrovskaya O.G., Popov I.C., Zhernova G.G., 1991. Set of maps of coal metamorphism of Donets basin, scale 1:500 000 (on the Paleozoic surface, sections $-400 \mathrm{~m},-1000 \mathrm{~m},-1600 \mathrm{~m}$ and on the structural plans of coal beds $c_{1}{ }^{6}$ and $k_{5}$ ). Kiev: GlavKGU "Ukrgeologiya", 14 sheets (in Russian).

Leskevich I.E., Savchuk S.V., 1961. Kaolinite in the Lower Carbonic Coals of the Western Donbass. Doklady AN SSSR, vol. 137, № 5, p. 1206-1208 (in Russian).

Lukinov V.V., Pimonenko L.I., 2008. Tectonics of methane and coal deposits of Donets Basins. Kiev: Naukova Dumka, 352 p. (in Russian).

Nagorny Yu.N., Nagorny V.N., 1976. Features of geological development of Donets Basin. Geotektonika, № 1, p. 74-86 (in Russian).

Novik E.O., 1974. Regularities in the development of the coal flora of the south of the European part of the USSR. Kiev: Naukova Dumka, 140 p. (in Russian).

Pimonenko L.I., Sakhnevich N.V., Poliakova N.S., 1992 Tectonic disturbance and geothermal regime of the Western Donbas. Geologiya i geokhimiya goryuchykh kopalyn, № 3, p. 50-58 (in Russian).

Privalov V.A., 2002. Methane in coal-bearing thickness of the Carboniferous of the Donbas. Geological aspects of generation, migration and the conditions of preservation. Geologiya i geokhimiya goryuchykh kopalyn, № 2, p. 61-83 (in Russian).

Stratigraphy of Upper Proterozoic and Phanerozoic of Ukraine. Vol. 1. Stratigraphy Proterozoic, Paleozoic and Mezozoic of Ukraine, 2014. (Sci. ed. P.F. Gozhik). Kyiv: Logos, 634 p. (in Ukrainian).

Teteryuk V.K., 1984. Paleoecological studies of microspores of Carboniferous peat-forming plants. Sovetskaya geologiya, № 11, p. 69-77 (in Russian).

Timofeev P.P., 1953. On the issue of the conditions for the sedimentation of coal-bearing suites $\mathrm{C}_{2}{ }^{6}$ and $\mathrm{C}_{2}{ }^{7}$ within the south-western margin of the Donbas. Doklady AN SSSR, vol. 93, № 6, p. 1091-1094 (in Russian).

Timofeev P.P., 2006. Evolution of the coal-bearing formations in the Earth's history. Moscow: Nauka, 204 p. (in Russian).

The coalbearing formations and matter composition of coals of Dnieper-Donets depression, 1990. (Ed. P.F. Shpak). Kiev: Naukova Dumka, 220 p. (in Russian). 
Uziyuk V.I., 1992. Layered synonymy of coal seams and intergrown rock interlayers of Donbas Geologiya $i$ geokhimiya goryuchykh kopalyn, № 3 (80), p. 46-50 (in Russian).

Usenko O.V., 2002. Heat flow and modern activation of the Donetsk basin (according to new data). Geofizichesky zhurnal, vol. 24, № 5, p. 102-111 (in Russian).

Feofilova A.P., Levenshtein M.L., 1963. Features of sedimentation and coal accumulation in the Lower and Middle Carboniferous of Donets Basin. Moscow: Izdatelstvo AN SSSR, iss. 73, 175 p. (in Russian).

Chernov'yants M.G., 1992. The tonshteins and its use for coal formation study. Moscow: Nedra, 144 p. (in Russian).

Shulga V.F., 1981. Lower Carboniferous coal bearing formation of Donets Basin. Moscow: Nauka, 176 p. (in Russian).

Shulga V.F., Ignatchenko N.A., Zaitseva L.B., 1987. Coal-bearing sediments and coals of the Lower Carboniferous of Dono-Dnieper trough. Atlas of litho-

\section{Список літератури}

Бердюкова М.Д., Иносова К.И., Ищеенко А.М., Коломейцева А.К., Лифшиц М.М., Пазухина Д.К., Шараева Л.Н., Широков А.З. Атлас углей нижнего карбона Донецкого бассейна. Москва: Наука, 1964. $205 \mathrm{c}$.

Вакарчук Г.И., Гавриш В.К. Перерывы и несогласия в разрезе палеозоя Днепровско-Донецкой впадины. Геол. журн. 1991. № 1 (256). С. 119-131.

Вассоевич Н.Б., Лейфман И.Е. Об оценке доли водорода, определяющей нефтематеринский потенциал органического вещества. Нефтематеринские свиты и принцииьы их диагностики. Москва: Наука, 1979. С. $36-46$.

Видавский В.В., Рябоконева Н.Я. Органическая масса донецких углей в связи с их коксуемостью. Геолого-углехимическая карта Донеикого бассейна. Вып 5. Харьков; Москва: Укргостопиздат, 1941. C. 432-514.

Власов В.М., Иванов Г.А. К определению степени восстановленности углей по литологическим данным. Вопросы метаморфизма углей и эпигенеза вмещцаюиих пород. Ленинград: Наука, 1968. С. 45-50.

Вялов В.И., Гуревич А.Б., Косинский В.А. Качество углей. Петрологический атлас ископаемого органического вещества России. Санкт-Петербург: ВСЕГЕИ, 2006. С. 29-72.

Геология месторождений угля и горючих сланцев СССР. Т. 1. Москва: Госгеолтехиздат, 1963. 1210 с.

Геология СССР. Геологическое описание. Северный Кавказ: Андрущук В.Л., Дубинский А.Я., Хаин В.Е. (ред.). Т. 9. Ч. 1. Москва: Недра, 1968.760 с. genetic types of rocks and coals. Kiev: Naukova Dumka, 136 p. (in Russian).

Shulga V.F., Ivanova A.V., Zaitseva L.B., Pankova M.G., 2010. Climatic zoning and petrographic composition of Early Carboniferous coal of East European platform. Geologichnyy zhurnal, № 1 (330), p. 58-65 (in Russian).

International Standart. Classification coals, 2005. ISO 11760: 2005 (in English).

Levenshtein, M.L, Spirina, O.I. 1984. Standard scale of metamorphism for claraine coals of Donets basin. Report on the meeting of the section 14 of 27 th International Congress (Moscow, 4-14 August, 1984). Abstracts, vol. 9, part 2, p. 302-304 (in English).

Sachsenhofer R.F., Privalov V.A., Izart A., Elie M., Kortensky J., Panova E.A., Sotirov A., Zhykalyak M.V., 2003. Petrography and geochemistry of Carboniferous coal seams in the Donets Basin (Ukraine): implications for paleoecology. Int. J. Coal. Geol., vol. 55, p. 225 (in English).

Гойжевский А.А., Науменко В.В., Скаржинский В.И. Тектоно-магматическая активизация регионов Украины. Киев: Наук. думка, 1977. 120 с.

Егоров А.И. Угленосные и горючесланцевые формации Европейской части СССР. Ростов-н/Дону: Изд-во Ростов. ун-та, 1985. 192 с.

Закономерности угленакопления на территории Западного Донбасса: А.З. Широков (ред.). Москва: Госгортехиздат, 1963. 452 с.

Зарицкий П.В. Межугольные прослои (тонштейны, kaolin-kohlentonstein) - продукты преобразования вулканического пепла в процессе углефикации (на примере Донбасса). Диагностика вулканогенных продуктов в осадочной толще: Материалы Рос. совещ. с междунар. участием. Сыктывкар: ИГ Коми НЦ УрО РАН, 2012. С. 121-123.

Иванова A.B. Геолого-генетические и петрохимические факторы засоления углей Западного Донбасса. Геол. журн. 1985. № 3 (222). С. 25-33.

Иванова А.В. Методика обработки данных витринитовой термометрии для проведения палеогеотермических и палеотектонических реконструкций. Геол. журн. 1992. № 6 (267). С. 32-36

Иванова А.В. Генезис і еволюція солоного вугілля України та проблеми його освоєння: автореф. дис. ... д-ра геол. наук / Ін-т геол. наук НАН України. Київ, 2016. 40 с.

Иванова A.В., Кривега T.A. Соленые угли Западного Донбасса. Киев: Наук. думка, 1985. 124 с.

Іванова A.В., Зайцева Л.Б. Роль геодинаміки в торфонакопиченні та формуванні речовинно-петро- 
графічного складу вугілля Західного Донбасу. Тектоніка і стратиграфія. 2014. Вип. 41. С. 40-48.

Клер В.Р., Жаров Ю.Н., Сливинская И.И. О распределении натрия и калия в углях. Докл. АН СССР. 1988. Т. 298, № 4. С. 936-938.

Кутас Р.И., Цвященко В.А. Тепловые процессы в геологической истории Донбасса. Геофиз. журн. 1993. Т. 15, № 2 (21). С. 42-53.

Левенштейн М.Л., Спирина О.И Комплект карт метаморфизма углей Донецкого бассейна м-ба 1:500 000 (поверхности палеозоя, срезов -400 м, -1000 м, -1600 м и структурных планов угольных пластов $c_{1}{ }^{6}$ и $k_{5}$ ). Объяснительная записка. Киев: ЦТЭ, 1991. $104 \mathrm{c}$.

Левенштейн М.Л., Спирина О.И., Носова К.Б., Дедов С.В., Дубровская О.Г., Попов И.С., Жерновая $\boldsymbol{\Gamma}$.Г. Комплект карт метаморфизма углей Донецкого бассейна (поверхности палеозоя, срезов: -400 м, -1000 м, -1600 м и структурных планов угольных пластов $c_{6}{ }^{l}$ и $\left.k_{5}\right)$. М-б 1:500 000. Киев: ГлавКГУ «Укргеологии», 1991. 14 л.

Лескевич И.Е., Савчук С.В. Каолинит в нижнекарбоновых углях Западного Донбасса.. Докл. АН CCCP, 1961. Т. 137, № 5. C. 1206-1208.

Лукинов В.В., Пимоненко Л.И. Тектоника метаноугольных месторождений Донбасса. Киев: Наук. думка, 2008. 352 с.

Нагорный Ю.Н., Нагорный В.Н. Особенности геологического развития Донецкого бассейна. Геотектоника. 1976. № 1. С. 74-86.

Новик Е.О. Закономерности развития каменноугольной флоры юга Европейской части СССР. Киев: Наук. думка, 1974. 140 с.

Пимоненко Л.И., Сахневич Н.В., Полякова Н.С. Тектоническая нарушенность и геотемпературный режим Западного Донбасса. Геологія $i$ геохімія горючих копалин. 1992. № 3. С. 50-58.

Привалов В.A. Метан в угленосной толще карбона Донбасса. Геологические аспекты генерации, миграции и условия сохранности. Геологія і геохімія горючих копалин. 2002. № 2. С. 61-83.

Cтратиграфія верхнього протерозою та фанерозою України: у 2 т. Т. 1: Стратиграфія верхнього протерозою, палеозою та мезозою України: Гожик П.Ф. (наук. ред.). Київ: Логос, 2014. 634 с.

Тетерюк В.К. Палеоэкологические исследования микроспор торфообразующих растений карбона. Сов. геология. 1984. № 11. С. 69-77.
Tимофеев П.П. К вопросу об условиях осадконакопления угленосных свит $\mathrm{C}_{2}{ }^{6}$ и $\mathrm{C}_{2}{ }^{7}$ в пределах юго-западной окраины Донбасса. Докл. АН СССР. 1953. Т. 93, № 6. С. 1091-1094.

Тимофеев П.П. Эволюция угленосных формаций в истории Земли. Москва: Наука, 2006. 204 с.

Угленосные формации и вещественный состав углей Днепровско-Донецкой впадин: Шпак П.Ф. (ред.). Киев: Наук. думка, 1990. 220 с.

Узиюк В.И. Послойная синонимика угольных пластов и межугольных породных прослоев Донбасса. Геологія і геохімія горючих копалин. 1992. № 3 (80). C. 46-50.

Усенко О.В. Тепловой поток и современная активизация Донецкого бассейна (по новым данным). Геофиз. журн. 2002. Т. 24, № 5. С. 102-111.

Феофилова А.П., Левенитейн М.Л. Особенности осадко- и угленакопления в нижнем и среднем карбоне Донецкого бассейна. Москва: Изд-во АН СССР, 1963. Вып. 73.175 с.

Черновьяни М.Г. Тонштейны и их использование при изучении угленосных формаций. Москва: Недра, 1992. $144 \mathrm{c.}$

Шульга В.Ф. Нижнекарбоновая угленосная формация Донецкого бассейна. Москва: Наука, 1981. 176 с.

Шульга В.Ф., Игнатченко Н.А., Зайцева Л.Б. Угленосные отложения и угли нижнего карбона ДоноДнепровского прогиба. Атлас литогенетических типов пород и углей. Киев: Наук. думка, 1987. 136 с.

Шульга В.Ф., Иванова А.В., Зайцева Л.Б., Панкова М.Г. Климатическая зональность и петрографический состав углей раннего карбона ВосточноЕвропейской платформы. Геол. журн. 2010. № 1 (330). C. 58-65.

International Standart Classification coals. ISO 11760: 2005.

Levenshtein M.L, Spirina O.I. Standard scale of metamorphism for claraine coals of Donets basin. Report on the meeting of the section 14 of 27th International Congress (Moscow, August 4-14, 1984). Abstracts, vol. 9, pt. 2, p. 302-304.

Sachsenhofer R.F., Privalov V.A., Izart A., Elie M., Kortensky J., Panova E.A., Sotirov A., Zhykalyak M.V. Petrography and geochemistry of Carboniferous coal seams in the Donets Basin (Ukraine): implications for paleoecology. Int. J. Coal. Geol. 2003. Vol. 55. P. 225-259.

Received Fevruary 5, 2018 